\title{
The Settlement Game: A Simulation Teaching Institutional Theories of Public Law
}

\author{
Dave Bridge, Baylor University
}

ABSTRACt Many political science subfields use classroom simulations. Public law, however, suffers from a lack of such activities. Many mock trials exist, but these games focus on jurisprudence and not on the more institutional aspects of the subfield. This article presents the Settlement Game, an original simulation that takes 15 minutes to complete and helps teach important institutional theories such as adversarial legalism, "bargaining in the shadow of the law," and "haves" versus "have-nots" concepts heretofore overlooked by the simulations literature. I introduce relevant theories and describe how the simulation works, discussing preclass assignments, its operation, and debriefing about its connection to theory. I close with comments about assessment of students and explain why the Settlement Game is useful.

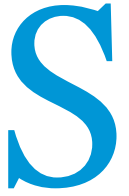

imulations are an increasingly popular way to teach about political science. They engage students in a fresh way, especially reaching out to those who respond to a more active learning style (Lamy 2000; 2007). Given their numerous educational benefits-including increased participation and reinforcement and retention of readings, lectures, and discussions (Asal 2005; Asal and Blake 2006; Smith and Boyer 1996; Wedig 2010) - it is no wonder that so many subfields across the discipline use simulations. The method is widely employed in American politics (Baranowski and Weir 2010; Coffey, Miller, and Feuerstein 2011; Lay and Smarick 2006), comparative politics (Endersby and Shaw 2009; Shaw 2006; Switky 2004), international relations (Bridge and Radford 2013; Raymond and Sorensen 2008; Switky and Aviles 2007), political theory (Gorton and Havercroft 2012; Pautz 2011), and public policy (Baranowski 2006; Jenkins 2010; Rinfret 2012).

However, public law suffers from a lack of published simulations. Granted, many mock trials teach jurisprudence by placing students in the role of litigators or judges whereby students grapple with issues of criminal or constitutional law (Baker 1994; Bengston and Sifferd 2010; Fliter 2009; Hardy, Rackaway, and Sonnier 2005; Hensley 1993; Pacelle 1989). Meanwhile, the institutional side of public law remains largely without simulations. Theories such as adversarial legalism (i.e., the institutional design of American trial courts) or "bargaining in the shadow of the law" (i.e., that litigants negotiate with the threat of going to court) are important tenets of the subfield, and yet, they are unaccounted for in the simulations literature (but see Weiden 2009). Jurisprudence is important, and for that reason, mock trials continue to have a

Dave Bridge is an assistant professor in the department of political science at Baylor University. He can be reached at david_bridge@baylor.edu. place in the simulations literature and the classroom. Institutional theories, however, are also a major part of public law, and perhaps the time has come to model games after them.

With this in mind, I present the Settlement Game, a 15-minute simulation that impressively models many institutional aspects within public law. The game is applicable, quick, and fun. Most importantly, it helps students learn about theories that heretofore have been largely ignored by the simulations literature. I start by introducing relevant public law theories. Then I describe how the simulation works, discussing preclass assignments, its operation, and debriefing about its connection to theory. I close with comments about assessment of students, and explain why the Settlement Game is useful.

\section{THEORIES IN PUBLIC LAW}

Many theories about American civil litigation trace back to adversarial legalism (Kagan 2001; see also Miller and Barnes 2004). A framework for thinking about how the United States structures its courts, the theory highlights the United States as a partydriven system in which the litigants steer the legal process by engaging in discovery, bringing and questioning witnesses, introducing evidence, and so forth. This contrasts to European-style bureaucratic legalism (or what others call the inquisitorial system), in which the judge controls discovery, witnesses, and evidence (Jacob et al. 1996; Kagan 2001). ${ }^{1}$ Because adversarial legalism inflicts high monetary costs on plaintiffs and defendants, often it is in the best interest of both parties to seek out-of-court settlements (Galanter and Cahill 1994). For example, a plaintiff seeking $\$ 1$, ooo might accept a settlement amount of $\$ 750$ if the legal fees cost $\$ 300$. Similarly, the defendant might jump at the offer of $\$ 750$, especially if the defendant's legal fees also cost $\$ 300$. In the end, the parties settle because the plaintiff nets more money $(\$ 750$ 
Table 1

Public Law Theories Modeled by the Settlement Game

\begin{tabular}{|c|c|c|}
\hline NAME & THEORY & SIMULATION \\
\hline Adversarial legalism & $\begin{array}{l}\text { The party-driven nature of US courts will engender } \\
\text { settlements (Kagan 2001). }\end{array}$ & The nature of the game causes settlements. \\
\hline Settlement & Most civil cases settle (Galanter and Cahill 1994). & Cases rarely go to trial. \\
\hline Bargaining in the shadow of the law & $\begin{array}{l}\text { There is always recourse to the courts, but settling } \\
\text { is easier (Mnookin and Kornhauser 1979). }\end{array}$ & $\begin{array}{l}\text { Either player can unilaterally take a case to trial, thereby } \\
\text { affecting negotiations. }\end{array}$ \\
\hline Cost of litigation & $\begin{array}{l}\text { Sometimes it is in the best interest of both parties } \\
\text { to settle (Kagan 2001). }\end{array}$ & To avoid litigation expenses, players settle. \\
\hline Haves versus have-nots & $\begin{array}{l}\text { Those who come to trial with more resources are } \\
\text { at an advantage (Galanter 1974). }\end{array}$ & If the cost of litigation is low, one is at an advantage. \\
\hline Incomplete information & $\begin{array}{l}\text { Litigants do not know all the details of the opposition's } \\
\text { case. }\end{array}$ & $\begin{array}{l}\text { Players do not know the value of all their opponent's } \\
\text { cards. }\end{array}$ \\
\hline Risk aversion & $\begin{array}{l}\text { Strategies will depend on an individual's aversion } \\
\text { to risk. }\end{array}$ & Some players are riskier than others. \\
\hline Self-help & $\begin{array}{l}\text { Litigants need not turn to a third party for dispute } \\
\text { resolution (Puzo 2002). }\end{array}$ & Players can avoid a trial by settling. \\
\hline Logic of the triad & $\begin{array}{l}\text { Litigants can turn to a neutral third party for dispute } \\
\text { resolution (Shapiro 1986). }\end{array}$ & If self-help fails, the option of a trial always exists. \\
\hline
\end{tabular}

versus $\$ 700)$, and the defendant pays less money ( $\$ 750$ versus $\$ 1,300)$.

The nature of the negotiations depends on several factors. The cost of litigation probably represents the most important variable. If legal fees are high, parties might be mutually better off settling out of court. Of course, one party might bring more resources to bear. Marc Galanter points to the problem of "haves" versus "have-nots" in the American legal system (1974). Galanter claims that "haves" carry certain advantages over "havenots," namely the financial capital needed to pursue long, expensive litigation. Two other items factor into the nature of settlements. First, incomplete information affects negotiations. For instance, before going to trial, the plaintiff does not know all the details of the defendant's narrative. If the plaintiff supposes those details are weak, he or she might be more willing to go to trial. If the plaintiff believes the details are strong, he or she might be more willing to settle. Second, some people are simply more risk averse than others, and they shy away from situations where the worst possible outcome is possible, even if highly improbable.

Whereas adversarial legalism lays the framework for formal court proceedings, that very structure incentivizes self-help and resolves some cases without formal proceedings. Granted, the bargaining process always takes place "in the shadow of the law" (Mnookin and Kornhauser 1979). That is, the threat of going to trial always remains, and therefore, formal institutions structure the informal negotiations. Put simply, the looming possibility of courts as a third party (Shapiro 1986) encourages settling.

The Settlement Game demonstrates all of the theories listed in the first column in table 1. It exhibits the adversarial legalism of US courts and the resulting bargaining under the shadow of the law. In addition, the game incorporates factors that affect the settlement process, such as the cost of litigation, unbalanced resources, incomplete information, and risk aversion. In the end, if litigants cannot solve cases through self-help settlements, recourse to the courts always is possible.

\section{OPERATION}

The Settlement Game uses an "explicit rule-based structure" (Bridge and Radford 2013; Raymond 2012, 76) to show processes, assumptions, and implications involved with civil litigation in the United States. The game is appropriate for a variety of courses in public law and American politics. The activity takes only 15 minutes to complete, although, instructors can use it for an entire class period by having students play more than one iteration. In addition, multiple games can be played at once, thereby overcoming the (usually valid) criticism that simulations cannot be used in larger classes (Asal 2005; Smith and Boyer 1996; Wheeler 2006). Each game requires a standard deck of playing cards. ${ }^{2}$

\section{Before the Simulation}

Many articles on simulation construction (e.g., Asal 2005; Asal and Blake 2006; Wedig 2010) suggest preclass assignments (typically, readings) that prime learning by helping students explore underlying theories. Then, simulations reinforce these theories by giving students a better appreciation of their real-world applicability. Because the Settlement Game taps into many public law theories, instructors have numerous options for preclass readings: passages from books (Kagan 2001, 6-14; Shapiro 1986, 1-8), articles (Galanter 1974; Galanter and Cahill 1994; Mnookin and Kornhauser 1979), and even the first pages of The Godfather where Bonasera seeks self-help outside the law by going to Don Corleone (Puzo 2002). Column two of table 1 provides a brief description of the readings' main points. Again, the readings introduce the theories to students prior to the simulation. The Settlement Game then highlights these theories in action.

\section{Gameplay}

The Appendix contains a handout describing the details of the simulation including helpful figures and tables that make the game easier to play. In brief, students take on the role of plaintiffs and defendants trying to settle four cases. They play one case at a time. The four cases are exactly identical: the plaintiff is suing for 
$\$ 15$. Each student plays the role of the plaintiff twice and the defendant twice. In every case, players can settle or take the case to trial, where either party could win. The nature of the settlement negotiations depends on six randomly dealt playing cards (see figure A1 in Appendix). Cards $\#_{1}, \#_{2}$, and $\#_{3}$ are dealt to the plaintiff. Cards $\#_{1}$ and $\#_{2}$ represent the strength of the plaintiff's case. The higher the value of these cards, the more likely the plaintiff will win the case if it goes to trial. Card \#1 faces up-both parties can see this card. Card \#2 faces down-only the plaintiff may look at this card. Meanwhile, Card \# 3 represents the cost of litigation. It faces down-only the plaintiff may look at this card. If the case goes to trial, the plaintiff is responsible for paying the amount on Card \#3, regardless of whether he or she wins or loses the case. The defendant also receives three cards. Card $\#_{4}$ faces down and represents the defendant's cost of litigation. Cards \#5 and \#6 represent the strength of the defendant's case. Card \#5 faces down and Card \#6 faces up.

The defense starts the game by offering a settlement amount ranging from $\$ 1-15$. The plaintiff can then accept the offer, counter the offer, or take the case to trial. If the plaintiff counters (which is likely), the defense can then accept, counter, or go to trial. The process repeats until the case settles or goes to trial. Either side can take the case to trial at any time. If the case goes to trial, the side with the higher strength of case cards wins (i.e., Cards \#1+\#2 versus Cards \# ${ }_{5}+\# 6$ ). 3 To help illustrate the game in action, a brief instructional video shows students playing the simulation. The video demonstrates how the game works, and the rationale behind each litigant's negotiation strategy. I recommend that instructors watch the video and consider sharing it with students. ${ }^{4}$ ment Game, students instantly recognize two issues: the mutual advantage of both litigants to settle, and the difficulty of dealing with incomplete information. If the cost of litigation cards $\#_{3}$ and \#4) are high, then both parties have mutual incentive to avoid paying those amounts altogether. The only way to do so is to settle. However, because neither side can see the other's cost of litigation cards, students both have incentive to try to convince the other side that their card is a low number and that they are willing to go to trial, if necessary. By "bluffing," they can better extract a more favorable settlement amount. In addition, some students even try to explain the financial situation to the opponent. For example, defendants might say, "I am offering \$10. Unless your cost of litigation (i.e., Card \#3) is lower than ' 5 ,' you will lose money if you take this case to trial." A strategic response would be, "Well, my costs (i.e., Card \#3) are '2,' so you better up your offer to $\$ 13$ or I am going to trial."

Students also highlight that each side only has half of the information needed to assess the opposition's strength of case. While Cards \# 1 and \#6 are viewable to all, only the plaintiff knows Card $\#_{2}$ and only the defense knows Card \#5. The plaintiff stands at a considerable advantage if Card \#1 is high and Card \#6 is low, and vice versa for the defendant. Nevertheless, the plaintiff can overcome a low Card \#1 with a high, face-down, Card \#2. Thus, the plaintiff should try to convince the defense that the face-down Card \#2 is a high card. For example, the plaintiff might say, "You think that my face-up ' 8 ' is an average card, but my face-down Card \#2 is a 'King.' If we go to trial, you will lose \$15 plus the cost of litigation (i.e., Card \#4). Aren't you better off just settling for $\$ 14$ ?" A strategic response would be, "I don't believe you. I think

\section{Again, the readings introduce the theories to students prior to the simulation. The Settlement Game then highlights these theories in action.}

After each settlement or trial, students calculate their gain or loss. If settled, the plaintiff gains the settlement figure while the defense loses the same figure. Neither side is responsible for their respective Card \# 3 or Card \# 4 cost of litigation. If the case goes to trial, the gain or loss depends on who wins. If the plaintiff wins the trial (i.e., Cards $\#_{1}+\#_{2}>$ Cards $\#_{5}+\# 6$ ), the defense pays $\$ 15$. If the defense wins the trial (i.e., Cards $\#_{5}+\# 6>$ Cards $\#_{1}+\#_{2}$ ), the defense pays \$o. Regardless of who wins, each side is responsible for the cost of litigation: the plaintiff pays the amount on Card \# 3 and the defense pays the amount on Card \#4. Table A2 in the Appendix assists students in calculating these amounts.

The cards are returned to the deck, which is then shuffled, and six more cards are again dealt. At the end of the four cases (about 15 minutes), students tally their net winnings or losses. The simulation can end there; or students can play multiple iterations of the game-perhaps against different opponents-within the same class period. In either case, students can compare their net gains or losses with every other student. If instructors want to add even more friendly competition, they can declare the largest net gainer as the overall winner. ${ }^{5}$

\section{After the Simulation}

After the simulation, the instructor should debrief with the class about the implications of the activity. Every time I run the Settle- your Card \# 3 is a low number and you would lose to my ' 9 ' and 'Queen.' Just in case you are bluffing, you might want to think about taking the \$1 I'm offering. At least that way, you don't lose money by losing the trial and paying the cost of litigation fees."

While settlement and incomplete information are the two most common items mentioned in the debriefing, the simulation illustrates all of the theories in table 1 (see third column). Depending on the syllabus and assigned readings, instructors can emphasize any of the theories. For instance, the simulation exemplifies how the parties, as described by adversarial legalism, dominate the legal process. The cost of litigation encourages those parties to seek self-help via out-of-court settlements. The final dollar amount on those settlements sometimes depends on the relative resources of the litigants, as "haves" can exert extra pressure on "havenots." In some cases, the final amount depends on how risky each litigant is. In other cases, litigants cannot reach a settlement, and they must take the case to trial showing the need for neutral third parties in dispute resolution. Even if the case never goes to trial, the bargaining takes place in the shadow of the law, where recourse to the courts always looms as a viable threat.

\section{ASSESSMENT}

The simulation lends itself to multiple ways of assessing students. During the activity, instructors can grade students on how 
seriously they took the simulation. Because the game involves an element of friendly competition, attentiveness has never been a problem. A better assessment tool is a follow-up essay based on the theories raised by the activity. Here are two of the many essay options: First, ask students to analyze whether settling is just. Students must first define what they mean by "just." Then, they use examples from the simulation to discuss how civil litigation fits with that definition. Typically, the essays turn on whether students are comfortable with litigants deciding their own resolution outside the courtroom. Second, ask students to use the readings and the simulation to analyze the factors that matter most in a court case. This prompt provokes various answers, including the law, the facts, money, and the will or mettle of the litigants. In both essays, students make good use of the simulation throughout their papers.

When students have anonymously assessed the simulation itself, they make several recurring comments: they appreciate the relevance of the game, enjoying its "real world applicability," "real application," and "real-life setting." One student commented, "It was as true to life as any simulation possibly could be in a classroom setting." Students also acknowledge the pedagogical advantage of the game in that it models so many public law theories so well. Some note the negotiation/settling aspect. Others like that there was incomplete information, prompting them to "try to convince other teams that you had better stuff than you did." From teaching about adversarial legalism to bargaining in the shadow of the law to "haves" versus "have-nots," the Settlement Game is a treasure trove for educators. This adaptability makes it appropriate for a diversity of classes in public law and American politics.

Finally, many comments describe how fun the game is and how it makes learning more enjoyable. Granted, in my first run, students remarked on the complexity of the game. Since then, I found two ways to eliminate this problem. First, as with any simulation, the instructor should circulate throughout the room, ensuring students understand how the rules work. More important, I now distribute the rules and make the instructional video available during the class session before the simulation begins. Most students then come to class understanding how the game works. Since I have begun handing out the rules beforehand, I rarely receive complaints about complexity. In addition, the video is exceedingly helpful. It shows the game in action, with helpful visuals provided on-screen.

\section{CONCLUSION}

The Settlement Game taps into many of public law's institutional theories, which until now, had largely been missing from the simulations literature. By placing students in a litigious setting with an explicit rule-based structure, they better understand many important theories of public law. The Settlement Game is interactive, quick, and fun. Most important, it provides an engaging way for students to absorb, retain, and apply key concepts.

\section{NOTES}

1. As Weiden (2009) notes, many countries in Latin America and Africa also use bureaucratic legalism.

2. Most simulations are limited to smaller classes because they rely on a single role-playing scenario with a limited number of roles. The Settlement Game allows for multiple games at once. The only limitation to the Settlement Game is the number of decks of cards an instructor can provide, because each game requires one deck of cards. In large classes $(50+)$, I ask students to bring a deck of cards to class, if convenient. When I have done this, I have always had more decks than necessary.
3. If the plaintiff and defense have the same totaling strength of case, the defense wins.

4. The video can be found at https://www.youtube.com/watch?v=Oliw2 $\mathrm{P}_{35}$ soU.

5. If instructors choose to do this, I recommend telling students that they are not just playing against a particular plaintiff or defendant, but against the entire class. Instructors might also consider marginal extra credit to spur friendly competition (Endersby and Shaw 2009; Raymond 2012).

\section{REFERENCES}

Asal, Victor. 2005. "Playing Games with International Relations." International Studies Perspectives 6 (3): 359-73.

Asal, Victor, and Elizabeth L. Blake. 20o6. "Creating Simulations for Political Science Education." Journal of Political Science Education 2 (1): 1-18.

Baker, Nancy V. 1994. "Oyez, Oyez, Oyez: The Trials of Teaching the Supreme Court." PS: Political Science \& Politics 27 (2): 253-55.

Baranowski, Michael. 2006. "Single Session Simulations: The Effectiveness of Short Congressional Simulations in Introductory American Government Classes." Journal of Political Science Education 2 (1): 33-49.

Baranowski, Michael, and Kimberly Weir. 2010. "Power and Politics in the Classroom: The Effect of Student Roles in Simulations." Journal of Political Science Education 6 (3): 217-26.

Bengston, Teri J., and Katrina L. Sifferd. 2010. "The Unique Challenges Posed by Mock Trial: Evaluation and Assessment of a Simulation Course." Journal of Political Science Education 6 (1): 70-86.

Bridge, Dave, and Simon Radford. 2013. "Teaching Diplomacy by Other Means: Using an Outside-of-Class Simulation to Teach International Relations Theory." International Studies Perspectives. onlinelibrary.wiley.com.

Coffey, Daniel J., William J. Miller, and Derek Feuerstein. 2011. "Classroom as Reality: Demonstrating Campaign Effects Through Live Simulation.” Journal of Political Science Education 7 (1): 14-33.

Endersby, James W., and Kelly B. Shaw. 2009. "Strategic Voting in Plurality Elections: A Simulation of Duverger's Law.” PS: Political Science \& Politics 42 (2): 393-99.

Fliter, John. 2009. "Incorporating a Sophisticated Supreme Court Simulation into an Undergraduate Constitutional Law Class." Journal of Political Science Education 5 (1): 12-26.

Galanter, Marc. 1974. "Why the 'Haves' Come Out Ahead: Speculations on the Limits of Legal Change." Law \& Society Review 9 (1): 95-16o.

Galanter, Marc, and Mia Cahill. 1994. "'Most Cases Settle': Judicial Promotion and Regulation of Settlements.” Stanford Law Review 46 (6): 1339-391.

Gorton, William, and Jonathan Havercroft. 2012. "Using Historical Simulations to Teach Political Theory." Journal of Political Science Education 8 (1): 50-68.

Hardy, Richard J., Chapman Rackaway, and Laurie E. Sonnier. 2005. "In the Supreme Court Justices' Shoes: Critical Thinking Through the Use of Hypothetical Case Law Analyses and Interactive Simulations." PS: Political Science $\mathcal{E}$ Politics 38 (3): 411-14.

Hensley, Thomas R. 1993. "Come to the Edge: Role Playing Activities in a Constitutional Law Class.” PS: Political Science \& Politics 26 (1): 64-68.

Jacob, Herbert, Erhard Blankenburg, Herbert M. Kritzer, Doris Marie Provine, and Joseph Sanders, eds. 1996. Courts, Law, and Politics in Comparative Perspective. New Haven, CT: Yale University Press.

Jenkins, Shannon. 2010. "Service Learning and Simulations." PS: Political Science $\mathcal{E}$ Politics 43 (3): 541-45.

Kagan, Robert A. 2001. Adversarial Legalism: The American Way of Law. Cambridge, MA: Harvard University Press.

Lamy, Steven L. 200o. "Teaching Introductory International Relations with Cases and Analytical Exercises." In The New International Studies Classroom: Active Teaching, Active Learning, eds. Jeffrey Lantis et al. Boulder, CO: Lynne Rienner.

- 2007. "Challenging Hegemonic Paradigms and Practices: Critical Thinking and Active Learning Strategies for International Relations." PS: Political Science \& Politics 40 (1): 112-16.

Lay, J. Celeste, and Kathleen J. Smarick. 2006. "Simulating a Senate Office: The Impact of Student Knowledge and Attitudes." Journal of Political Science Education 2 (2): 131-46.

Miller, Mark C., and Jeb Barnes, Eds. 2004. Making Policy, Making Law. Washington, DC: Georgetown University Press.

Mnookin, Robert H., and Lewis Kornhauser. 1979. "Bargaining in the Shadow of the Law: The Case of Divorce." Yale Law Journal 88 (5): 950-97.

Pacelle, Richard L. 1989. "Simulating Supreme Court Decision Making." Political Science Teacher 2: 9-11.

Pautz, Michelle C. 2011. "Challenging the Constitution: Convening a Mock Constitutional Convention for American Government Students." PS: Political Science \& Politics 44 (3): 648-51. 
Puzo, Mario. 2002. The Godfather. New York: Penguin Books.

Raymond, Chad. 2012. "Missing the Trees for the Forest?: Learning Environments versus Learning Techniques in Simulations." Journal of Political Science Education 8 (1): 69-84.

Raymond, Chad, and Kerstin Sorensen. 2008. "The Use of a Middle East Crisis Simulation in an International Relations Course." PS: Political Science \& Politics 41 (1): 179-82.

Rinfret, Sara R. 2012. "Simulating City Councils: Increasing Student Awareness and Involvement." PS: Political Science \& Politics 45 (3): 513-15.

Shapiro, Martin M. 1986. Courts: A Comparative and Political Analysis. Chicago: University of Chicago Press.

Shaw, Carolyn M. 2006. "Simulating Negotiations in a Three-Way Civil War." Journal of Political Science Education 2 (1): 51-71.
Smith, Elizabeth T., and Mark A. Boyer. 1996. "Designing In-Class Simulations." PS: Political Science \& Politics 29 (4): 690-94.

Switky, Bob. 2004. "Party Strategies and Electoral Systems: Simulation Coalition Governments." PS: Political Science \& Politics 37 (1): 101-04.

Switky, Bob, and William Aviles. 2007. "Simulating the Free Trade Area of the Americas." PS: Political Science \& Politics 40 (1): 399-405.

Wedig, Timothy. 2010. "Getting the Most from Classroom Simulations: Strategies for Maximizing Learning Outcomes.” PS: Political Science \& Politics 43 (3): 547-55.

Weiden, David L. 2009. "Comparing Judicial Institutions: Using an Inquisitorial Trial Simulation to Facilitate Student Understanding of International Legal Traditions." PS: Political Science \& Politics 42 (4): 759-63.

Wheeler, Susan M. 2006. "Role-Playing Games and Simulations for International Issues Courses." Journal of Political Science Education 2 (3): 331-47.

\section{APPENDIX: The Settlement Game}

You are either a plaintiff or a defendant fighting a series of cases. The plaintiff is suing for $\$ 15$ in each case. The plaintiff cannot settle for more than $\$ 15$. Each case is completely separate from the others. You must decide whether to settle or take each case to trial.

\section{INSTRUCTIONS}

Each team draws three cards. Two of them are face down, one is face up. See figure Al.

Figure A1

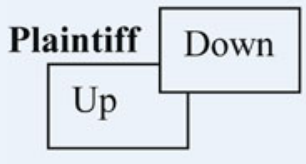

1 2

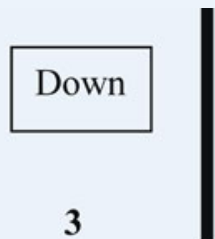

3

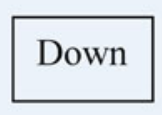

4

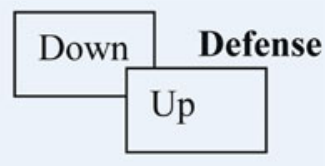

5

6

Card \#3 and Card \#4 represent the cost of litigation for the plaintiff and defendant, respectively. This is how much it will cost to go to trial. Only the plaintiff can see Card \#3. Only the defendant can see Card \#4. If you go to trial, the amounts on Card \#3 and Card \#4 are subtracted from the respective sides, regardless of who wins the trial.

Note: The plaintiff would do best to settle for anything > (15-Card \#3)

Card \#1+Card \#2 represents the strength of the plaintiff 's case. Both sides can see Card \#1. Only the plaintiff can see Card \#2. Card \#5+Card \#6 represents the strength of the defendant's case. Both sides can see Card \#6. Only the defendant can see Card \#5. If a case goes to trial, whichever side has a higher number (Card \#1+Card \#2 or Card \#5+Card \#6) wins. If tied, the defense wins. Card values are listed in table $\mathrm{A} 1$.

Table A1

\begin{tabular}{ccccccccc} 
CARD & $\mathbf{2}$ & $\mathbf{3}$ & $\ldots$ & $\mathbf{1 0}$ & JACK & QUEEN & KING & ACE \\
\hline Value & 2 & 3 & $\ldots$ & 10 & 11 & 12 & 13 & 14 \\
\hline
\end{tabular}

Before going to trial, the defense has to offer a settlement number (at least \$1). The plaintiff can reject, accept, or counter the offer. Repeat until the case is settled or goes to trial.

After each settlement or trial, calculate how much each side gained or lost. See table A2.

Table $\mathrm{A}_{2}$

SCENARIO

Settlement

Trial-Plaintiff wins

Trial-Defense wins
PLAINTIFF

DEFENDANT

+ settlement number

- cost of litigation (\$0)

$+\$ 15$

- cost of litigation (Card \#3)

$+\$ 0$

- cost of litigation (Card \#3)
- settlement number

- cost of litigation (\$0)

- $\$ 15$

- cost of litigation (Card \#4)

- \$0

- cost of litigation (Card \#4) 